\title{
Estetrol, a Fetal Selective Estrogen Receptor Modulator, Acts on the Vagina of Mice through Nuclear Estrogen Receptor $\alpha$ Activation
}

Thibaut Benoit, ${ }^{\dagger \dagger}$ Marie-Cecile Valera, ${ }^{*}$ Coralie Fontaine, ${ }^{*}$ Melissa Buscato, ${ }^{*}$ Francoise Lenfant, ${ }^{*}$ Isabelle Raymond-Letron, ${ }^{*}$ Florence Tremollieres, ${ }^{\S}$ Michel Soulie, ${ }^{\dagger}$ Jean-Michel Foidart, ${ }^{\top}$ Xavier Game, ${ }^{* \dagger}$ and Jean-Francois Arnal*

From INSERM, * U1048 and Universite Toulouse III, Metabolic and Cardiovascular Disease Institute, Toulouse, France; the Department of Urology, Andrology, and Transplantion, ${ }^{\dagger}$ Centre Hospitalier Universitaire Toulouse-Rangueil, Toulouse, France; the STROMALab, ${ }^{\ddagger}$ Universite de Toulouse, Centre National de la Recherche Scientifique, Ecole Nationale Veterinaire de Toulouse, INSERM U1031, Université Paul Sabatier, Toulouse, France; the Centre de Menopause, ${ }^{\S}$ Hopital Paule-deViguier, Toulouse, France; and the Laboratory of Tumor and Development Biology Groupe Interdisciplinaire de Génoprotéomique Appliquée-Cancer, " University of Liege, Liege, Belgium

\author{
Accepted for publication \\ July 13, 2017. \\ Address correspondence to \\ Thibaut Benoit, M.D., Depart- \\ ment of Urology, Andrology, \\ and Transplantion, Centre Hos- \\ pitalier Universitaire Toulouse- \\ Rangueil, 1 Ave du Pr Jean \\ Poulhes, 31059 Toulouse \\ Cedex 9, France; INSERM, \\ U1048, and Université Tou- \\ louse III, I2MC, Toulouse, \\ France. E-mail: benoit.t@chu- \\ toulouse.fr.
}

\begin{abstract}
The genitourinary syndrome of menopause has a negative impact on quality of life of postmenopausal women. The treatment of vulvovaginal atrophy includes administration of estrogens. However, oral estrogen treatment is controversial because of its potential risks on venous thrombosis and breast cancer. Estetrol (E4) is a natural estrogen synthesized exclusively during pregnancy by the human fetal liver and initially considered as a weak estrogen. However, E4 was recently evaluated in phase 1 to 2 clinical studies and found to act as an oral contraceptive in combination with a progestin, without increasing the level of coagulation factors. We recently showed that E4 stimulates uterine epithelial proliferation through nuclear estrogen receptor (ER) $\alpha$, but failed to elicit endothelial responses. Herein, we first evaluated the morphological and functional impacts of E4 on the vagina of ovariectomized mice, and we determined the molecular mechanism mediating these effects. Vaginal epithelial proliferation and lubrication after stimulation were found to increase after E4 chronic treatment. Using a combination of pharmacological and genetic approaches, we demonstrated that these E4 effects on the vagina are mediated by nuclear ER $\alpha$ activation. Altogether, we demonstrate that the selective activation of nuclear ER $\alpha$ is both necessary and sufficient to elicit functional and structural effects on the vagina, and therefore $\mathrm{E} 4$ appears promising as a therapeutic option to improve vulvovaginal atrophy. (Am J Pathol 2017, 187: 2499-2507; http://dx.doi.org/10.1016/j.ajpath.2017.07.013)
\end{abstract}

The genitourinary syndrome of menopause, including vulvovaginal atrophy (VVA) and lower urinary tract symptoms, ${ }^{1}$ affects approximately $50 \%$ to $60 \%$ of postmenopausal women. $^{2-5}$ The major symptoms of VVA are dyspareunia, vaginal dryness, itching, and incontinence. The use of estrogen orally, transdermally, subcutaneously, or vaginally has been shown to reduce and inhibit the progression and the symptoms of VVA. ${ }^{6-8}$ However, oral estrogen treatment is controversial and is prescribed today after an evaluation of the benefit-risk ratio because of its increased risk on venous thrombosis and breast cancer. ${ }^{9}$ These data deterred many women from initiating or continuing classic hormone replacement therapy. ${ }^{10}$ In this context, vaginal administration is a possible alternative treatment in women presenting contraindications for the oral route. Low-dose vaginal estrogen is actually the first-line treatment of VVA and has no risks on venous thromboembolism or breast cancer. ${ }^{11,12}$ However, this local treatment has some adverse effects, such as vaginal discharge or bleeding, ${ }^{13}$ and some patients show low compliance toward vaginal administration because of personal and/or cultural reasons.

Concerns about the potential risks or constraints of usual hormone replacement therapy lead to an active search for

Supported by the French Urological Association (T.B.).

Disclosures: None declared. 
innovative therapies. Selective estrogen receptor (ER) modulators are compounds characterized by specific tissue-selective actions, being agonists and mimicking some effects of estrogens while antagonizing others. ${ }^{14}$ An ideal selective ER modulator would preserve the beneficial effects of estrogens on the bone and urogenital system, and reduce their unwanted adverse effects, mainly increased risk of venous thrombosis and of breast cancer. Recent studies suggest that estetrol (E4) should be considered as an interesting candidate. Although discovered as early as $1965,{ }^{15}$ E4 was considered during several decades as a weak estrogen produced only by the human fetal liver during pregnancy. E4 was recently evaluated in phase 1 to 2 clinical studies and was found to have a good potential as an oral contraceptive when it was combined with a progestin in fertile women. ${ }^{16,17} \mathrm{E} 4$ was also efficient in preventing hot flushes in an experimental animal model. ${ }^{18}$ Previous animal and human studies indicate that E4 has estrogenic effects on ovariectomized rats ${ }^{19}$ and on the vaginas of postmenopausal women. ${ }^{20}$ The potency of E4 is approximately 20 -fold lower compared to ethinyl estradiol for the rat. ${ }^{19}$ In women, Coelingh Bennink et $\mathrm{al}^{20}$ found that 2 to $10 \mathrm{mg}$ E4/day restored a vaginal cytology equivalent to that elicited by chronic oral treatment with $2 \mathrm{mg}$ estradiol. E4 leads to a shift from parabasal to intermediate and superficial vaginal epithelial cells and an increase of the vaginal maturation index, as occurred in premenopausal women. ${ }^{20}$ Interestingly, E4 treatment does not increase the level of hepaticderived coagulation factors, and therefore appears as an interesting new selective ER modulator because it might not increase the risk of thrombosis. ${ }^{21}$

The biological effects of estrogens are mediated by their binding to the two ERs (ER $\alpha$ and $E R \beta)$, leading to conformational changes, dimerization, and recruitment of coactivators into the nucleus, where they interact with estrogen response elements or other transcription factors to modulate the transcription of target genes. ${ }^{22}$ Ligand-induced transcriptional activity of ER involves the action of two distinct activation functions (AFs), AF1 and AF2. The time lag between estrogen administration and observable transcriptional effects is typically in the order of hours to days. However, in addition to the nuclear (alias genomic) actions of ER, estrogens have been found to induce rapid effects occurring within minutes after administration. These effects are mediated through a subpopulation of receptors associated with the plasma membrane, a process usually termed membrane-initiated steroid signaling. ${ }^{23}$ A knock-in mouse model was recently generated by mutating the cysteine 451 palmitoylation site of ER $\alpha$ to alanine (designated C451A$\mathrm{ER} \alpha$ ), which provides a specific loss of function of membrane ER $\alpha{ }^{24} \mathrm{~A}$ mouse model for selective loss of function of nuclear ER $\alpha$ actions is also available, obtained after inactivation of $\mathrm{AF} 2$, consisting of a deletion of the amino acids 543 to 549 in the helix 12 of ER $\alpha$ (designated ER $\alpha$ $\left.\mathrm{AF} 2^{0}\right){ }^{24,25}$ Using combined genetic and pharmacological approaches, we proposed that E4 modulates ER actions in a tissue-specific manner through a selective nuclear, but not membrane, ER $\alpha$ activation. ${ }^{26}$ Thus, E4 should now be considered not as a weak estrogen, but rather as a selective ER modulator.

The aim of this study was to evaluate the morphological and functional impacts of $\mathrm{E} 4$ on the vagina of ovariectomized mice and to determine the molecular mechanisms mediating these effects. We showed that, in ovariectomized mice, E4 chronic treatment increased vaginal epithelial proliferation and vaginal lubrication after stimulation. Using a combination of pharmacological and genetic approaches, we demonstrate that these effects of E4 are mediated by nuclear $\mathrm{ER} \alpha$ activation.

\section{Materials and Methods}

\section{Mice}

Procedures were performed in accordance with the recommendations of the European Accreditation of Laboratory Animal Care and the guidelines established by the National Institute of Medical Research (INSERM). Female C57BL/ $6 \mathrm{~J}$ mice were purchased from Charles River (Malvern, PA). Mice targeted for ER $\alpha, \mathrm{ER} \beta, \mathrm{ER} \alpha-\mathrm{AF} 2$, and C451A-ER $\alpha$ mice have been previously described. ${ }^{24,25,27}$ Mice were anesthetized by injection of ketamine $(25 \mathrm{mg} / \mathrm{kg})$ and xylazine $(10 \mathrm{mg} / \mathrm{kg})$ in an i.p. route, ovariectomized or sham-operated at 4 weeks of age, and implanted, 3 weeks later, subcutaneously with 17-beta-estradiol (E2) pellets ( 8 or $80 \mu \mathrm{g} / \mathrm{kg}$ per day, 60 -day release; Innovative Research of America, Sarasota, FL), E4 minipumps (6 or $1 \mathrm{mg} / \mathrm{kg}$ per day, 28-day release; Alzet Durect Corp., Cupertino, CA), estrogen-dendrimer conjugate (EDC; $240 \mu \mathrm{g} / \mathrm{kg}$ per day), or empty dendrimer at a rate identical to that delivered with EDC as a control. EDC selectively activates ER membrane signaling. ${ }^{28,29}$ EDC was kindly provided by Sung Hoon Kim, John A. Katzenellenbogen, and Benita S. Katzenellenbogen (University of Illinois at Urbana-Champaign). Animals were euthanized after a 3-week treatment period. E2 doses of 8 and $80 \mu \mathrm{g} / \mathrm{kg}$ per day have been previously reported, to elicit a circulating plasma E2 level in the high range of the mouse estrous cycle and in pregnant mouse, respectively. ${ }^{30}$ Mice received two doses of E4 (1 or $6 \mathrm{mg} / \mathrm{kg}$ per day; ie, 25 or $150 \mu \mathrm{g} / \mathrm{day}$ per animal), in line with multiple in vivo animal and human data that show that human therapeutic equivalence of E4 in comparison to E2 requires a 3- to 15-fold higher dose. In addition, such E4 doses induce steady-state plasma levels of E4 equivalent to those found in women exposed to therapeutic doses (2.5 to $15 \mathrm{mg}$ ) of E4 and to those found in the plasma of term fetuses. ${ }^{26}$

\section{Cervical Vaginal Lubrication}

Cervical vaginal lubrication was evaluated in ovariectomized mice either left untreated or treated with E2, E4, or EDC, as 
previously described. ${ }^{31}$ Under anesthesia, the vagina was stimulated by five strokes within 5 seconds against the cervix by a 3 French (1.0-mm wide) Teflon-coated probe inserted into the vaginal lumen (3 French occlusion balloon catheter; Coloplast, Rosny-sous-Bois, France). One minute after the stimulation, a preweighed absorbent paper strip was inserted into the vagina for 10 seconds. Vaginal lubricate volume was calculated using the difference in the paper weights (in milligrams) after and before insertion (Mettler AC 100 analytical balance; Mettler Toledo, Viroflay, France).

\section{Histological Analysis, Immunohistochemistry, and Histomorphometry}

Mice were euthanized for histological analysis at 10 weeks of age after a 3-week treatment. Paraffin-embedded transverse sections (4 $\mu \mathrm{m}$ thick) from formalin-fixed vagina specimens were stained, as previously described, ${ }^{32}$ using the anti-Ki-67 (RM-9106; Thermo Fisher Scientific, Waltham, MA) and the anti-ER $\alpha$ (MC-20; Santa Cruz Biotechnology, Dallas, TX) antibodies. Images of whole vagina sections were acquired using a NanoZoomer Digital Pathology Scanner (Hamamatsu Photonics, Shizuoka, Japan). To examine the proliferative effect of each treatment, the ratio of Ki-67-positive epithelial/total cell number was evaluated in each vaginal section after two quantifications at $\times 20$ magnification. The luminal epithelial height was measured from the basal membrane to the apical surface, as described previously in the uterus. ${ }^{32}$ Briefly, the values of the epithelial height are the mean of 10 measurements in two transverse vaginal sections of each specimen.

\section{Protein Extraction and Western Blot Analysis}

Vagina specimens were removed en bloc, rinsed with ice-cold saline buffer, frozen by immersion in liquid nitrogen, and stored at $-80^{\circ} \mathrm{C}$. Total proteins from vagina were separated on a $10 \%$ SDS/PAGE gel and transferred to a nitrocellulose membrane. The membranes were then incubated with the primary monoclonal anti-ER $\alpha$ (60C; Millipore, Billerica, MA) and polyclonal anti- $\beta$-actin (A2066; Sigma, St. Louis, MO) antibodies. Subsequently, blots were incubated with a horseradish peroxidase-conjugated secondary antibody (SC2030; Santa Cruz Biotechnology) and visualized by electrochemiluminescence detection, according to the manufacturer's instructions (Amersham Biosciences, Piscataway, NJ), using a ChemiDoc Imaging System (Bio Rad Laboratories, Hercules, $\mathrm{CA})$. Bands corresponding to $\mathrm{ER} \alpha$ and $\beta$-actin were quantified using ImageJ software version 1.45S (NIH, Bethesda, MD; http://imagej.nih.gov/ij) densitometry, and the ratio of the band intensities was calculated.

\section{Analysis of mRNA Levels by Real-Time Quantitative PCR}

Vaginas were homogenized using a Precellys tissue homogenizer (Bertin Technology, Montigny-le-Bretonneux,
France), and total RNA from tissues was prepared using TRIzol reagent (Invitrogen, Carlsbad, CA). RNA was reverse transcribed using the High Capacity cDNA Reverse Transcriptase Kit (Applied Biosystems, Villebon sur Yvette, France). Real-time quantitative PCRs were performed on the StepOne instrument (Applied Biosystems). Primers were validated by testing PCR efficiency using standard curves $(95 \% \leq$ efficiency $\leq 105 \%)$. Gene expression was quantified using the comparative $\mathrm{C}_{\mathrm{T}}$ method; hypoxanthine guanine phosphoribosyl transferase 1 was used as a reference.

\section{Statistical Analysis}

Results are expressed as means \pm SDs or SEMs, as indicated. The effect of hormonal treatments and the genotypes were tested with a one- or two-factor analysis of variance model for repeated measurements, followed by pairwise comparisons with the Bonferroni post hoc test using Prism software version 5.1 (GraphPad Software, Inc., La Jolla, CA). $P<0.05$ was considered statistically significant.

\section{Results}

E4 Induces Morphological Changes in the Vagina and Increases Vaginal Lubrication

We previously showed that E4, a natural estrogen with four hydroxyl groups (Figure 1A), is less potent than E2 to activate $\mathrm{ER} \alpha$, but a 100-fold higher dose is able to modulate the transcriptional activity of ER $\alpha$ in the uterus as well as the proliferation of endometrial epithelium. ${ }^{26}$ To evaluate E4 effect on the vagina, mice were treated chronically with E2 ( 8 and $80 \mu \mathrm{g} / \mathrm{kg}$ per day) and E4 ( 1 and $6 \mathrm{mg} / \mathrm{kg}$ per day). $\mathrm{E} 2$ and E4 induced a similar increase in vaginal weight (E2, $80 \mu \mathrm{g} / \mathrm{kg}$ per day versus ovariectomized: $135.1 \pm 10.2$ versus $29.5 \pm 4.5 \mathrm{mg}$; and $\mathrm{E} 4,6 \mathrm{mg} / \mathrm{kg}$ per day versus vehicle: $124.3 \pm 12.1$ versus $36.5 \pm 12.1 \mathrm{mg}$; both $P<0.0001$ ), whatever the dose of estrogen compounds (Figure 1, B and C).

Histological analysis of the vagina revealed similar change in response to E2 or E4. Epithelium of ovariectomized mice was composed of only two cellular layers, and E2 or E4 treatments at both doses induced a large expansion of these cellular layers (Figure 1D). Both treatments similarly increase the epithelial height in comparison to untreated ovariectomized mice (Figure 1E). In addition, epithelial proliferation was evaluated by immunohistochemical detection of Ki-67 antigen. The percentages of cells that were positively stained with Ki-67 antibody were $38.9 \% \pm 7.3 \%$ for E2-treated mice and $30.5 \% \pm 6.1 \%$ for E4-treated mice (ie, similarly increased compared to untreated mice) (Figure 1E).

The vaginal lubrication was further measured to investigate the functional consequences of these hormonal treatments. Vaginal lubrication after cervical vaginal stimulation was significantly increased in E2- and E4-treated mice 
A

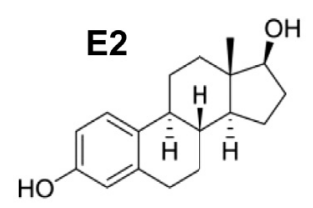

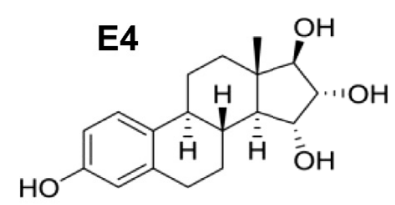

B

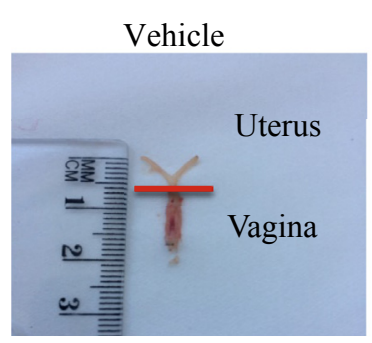

$\mathrm{E} 46 \mathrm{mg} / \mathrm{kg}$ per day

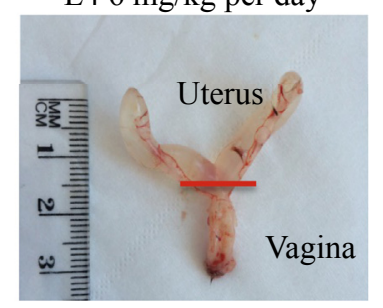

C

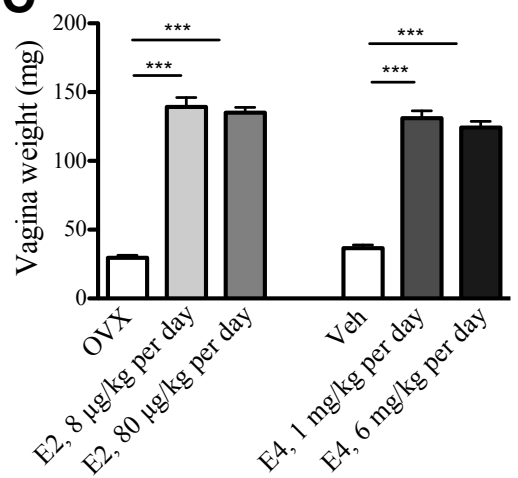

D

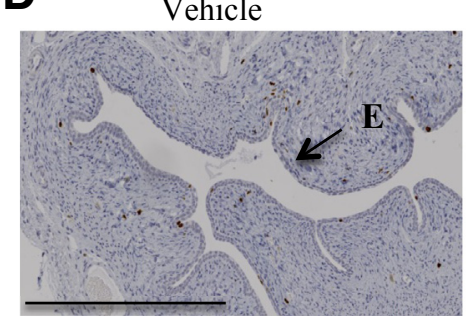

E2, $80 \mu \mathrm{g} / \mathrm{kg}$ per day

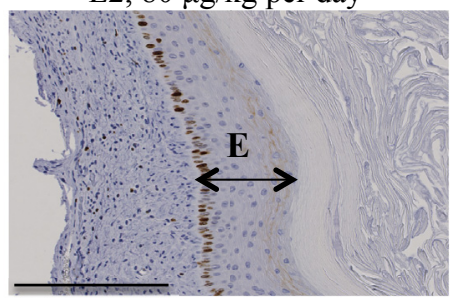

$\mathrm{E} 4,6 \mathrm{mg} / \mathrm{kg}$ per day

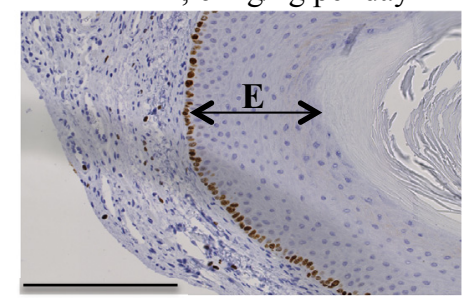

E
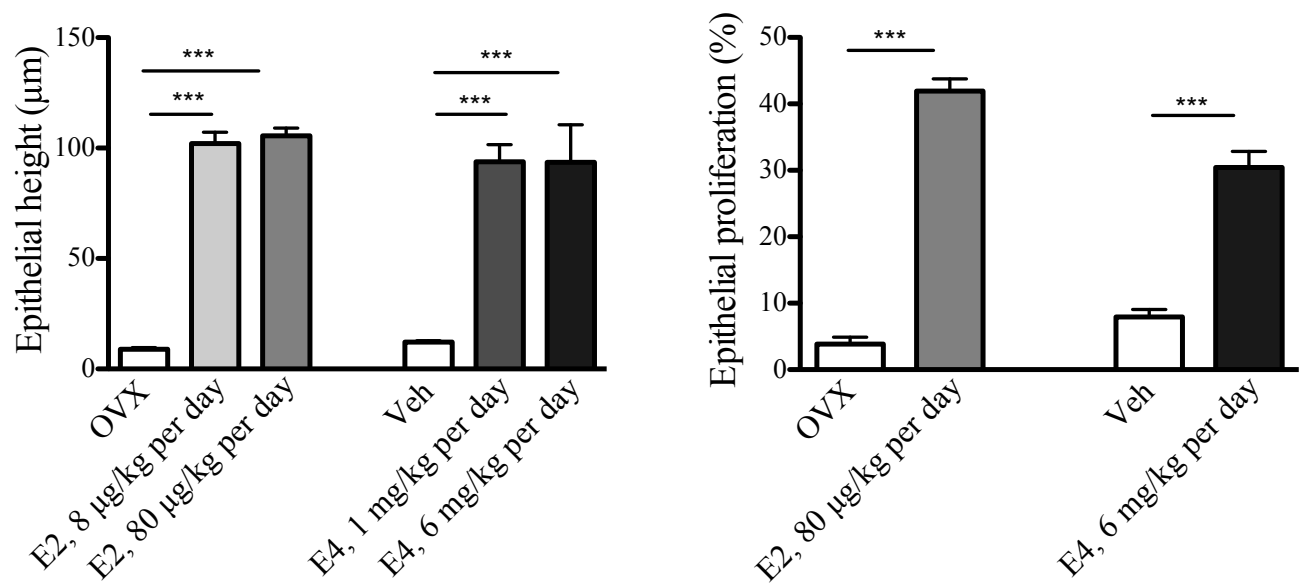

Figure 1 Effect of a chronic administration of estradiol (E2; 8 and $80 \mu \mathrm{g} / \mathrm{kg}$ per day) and estetrol (E4; $1 \mathrm{and} 6 \mathrm{mg} / \mathrm{kg}$ per day) on the vagina of mice. A: Chemical structures of E2 and E4. B: Macroscopic images of mouse uterus and vagina under vehicle (Veh) and E4, $6 \mathrm{mg} / \mathrm{kg}$ per day, chronic treatment. The red lines represent the limit between uterus and vagina. C: Vaginal weights from mice treated or not with E2 or E4. D: Representative images of Ki-67 immunolabeling in transverse vaginal sections. Arrowheads indicate the epithelium (E). E: Histological analysis of the vagina. Data are expressed as means \pm SD (C and $\mathbf{E}) . n=8$ (treatment versus placebo: one-factor analysis of variance; $\mathbf{C}$ and $\mathbf{E})$. ${ }^{* * *} P<0.001$. Scale bars: $400 \mu \mathrm{m}$ (D, left panel); $200 \mu \mathrm{m}(\mathbf{D}$, middle and right panels). Original magnification, $\times 20$ (D). 0VX, ovariectomized.

compared to untreated mice (Figure 2), with no difference between E4 and E2 treatment, whatever the dose. Altogether, this demonstrates a similar morphological and functional impact of chronic E2 and E4 on the vagina of ovariectomized mice.
Vaginal ER $\alpha$ Expression and Role of ER $\alpha$ in the Effect of E4

The respective roles of ER $\alpha$ and ER $\beta$ in the effects of E4 treatment at the dose of $6 \mathrm{mg} / \mathrm{kg}$ per day were studied using 


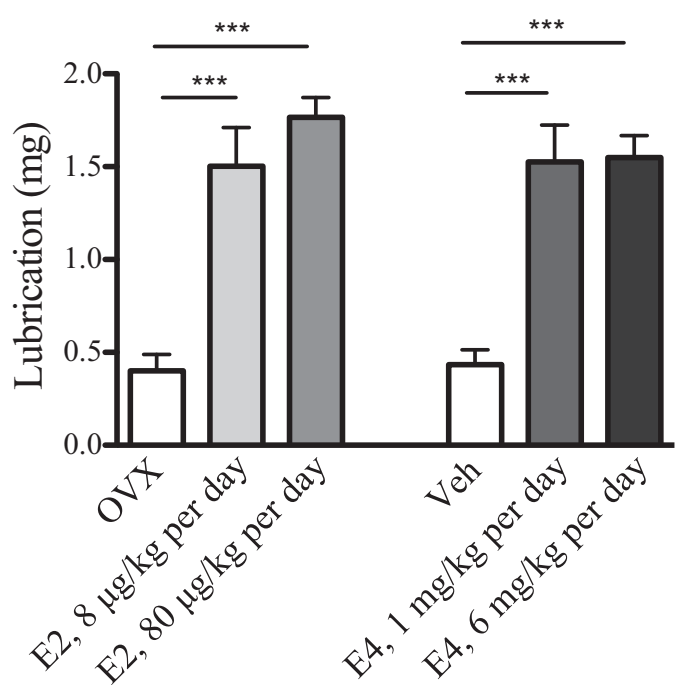

Figure 2 Evaluation of a chronic administration of estradiol (E2; 8 and $80 \mu \mathrm{g} / \mathrm{kg}$ per day) and estetrol (E4; 1 and $6 \mathrm{mg} / \mathrm{kg}$ per day) on vaginal lubrication. Data are expressed as means \pm SD. $n=8$ (treatment versus placebo: one-factor analysis of variance). ${ }^{* *} P<0.001$. OVX, ovariectomized; Veh, vehicle.

mice deleted for either ER $\alpha$ or ER $\beta$, respectively. Vaginal weight, epithelial height, or proliferation and vaginal lubrication after stimulation were not increased by $\mathrm{E} 4$ treatment in $\mathrm{ER} \alpha^{-1-}$ mice, whereas the effect of $\mathrm{E} 4$ was present in their $\mathrm{ER} \alpha^{+/+}$control littermates and similar to that observed in other wild-type mice (Table 1). In contrast, no differences were observed in the vaginal characteristics between $\mathrm{ER} \beta^{+/+}$and $\mathrm{ER} \beta^{-/-}$mice after $\mathrm{E} 4$ treatment (Table 1). These results demonstrate that, as previously demonstrated for $\mathrm{E} 2{ }^{33}$ the effects of $\mathrm{E} 4$ on the mouse vagina are entirely mediated through $\mathrm{ER} \alpha$, with $\mathrm{ER} \beta$ playing little, if any, role in this process.

ER $\alpha$ immunostaining and Western blot analysis were performed to evaluate the abundance of $E R \alpha$ protein in the vagina of ovariectomized vehicle-, E2-, or E4-treated mice. $\mathrm{ER} \alpha$ immunoreactivity was detected in both the vaginal epithelium and the stroma from ovariectomized vehicletreated mice, but to a lesser extent in E2- or E4-treated mice (Figure 3A). Accordingly, as shown in Figure 3B, using Western blot analysis, $\mathrm{ER} \alpha$ protein level in the vagina was significantly and similarly decreased by E2 and E4. This was associated with a marked decrease of ER $\alpha$ mRNA abundance (Figure 3C). Taken together, these results demonstrated that both chronic E2 and E4 treatment led to a pronounced decrease in ER $\alpha$ expression in the vagina of mice.

\section{The Effects of E2 and E4 on the Vagina of Mice Are Mediated by Nuclear ER $\alpha$ Activation}

A pharmacological approach was used to test the contribution of membrane ER $\alpha$ on the effect of estrogens on the vagina using an EDC that selectively activates ER membrane signaling (Figure 4A). The EDC has a high chemical stability, is free from traces of unattached ligand, and is specific in stimulating nongenomic responses. ${ }^{28,29}$ Chronic EDC treatment of ovariectomized mice did not alter epithelial height or vaginal lubrication (Figure 4B). These results indicate that selective membrane $\mathrm{ER} \alpha$ activation is not sufficient to elicit an action on vagina.

To further analyze the role of membrane versus nuclear $\mathrm{ER} \alpha$ activation in the effects of E4, a genetic approach was used. Mice lacking the ER $\alpha$ activation function AF2 $\left(\mathrm{ER} \alpha \mathrm{AF}^{0}\right)$ provide a selective loss of function of nuclear $E R \alpha$ actions. We first evaluated the effect of a chronic treatment of $\mathrm{E} 4$ on the vagina from $\mathrm{ER} \alpha \mathrm{AF} 2^{0}$ mice. Results showed that the vaginal response to E4 was completely abolished in $\mathrm{ER} \alpha \mathrm{AF}^{0}$ mice, whereas, as expected, the morphological and functional responses were normal in the wild-type littermates (Figure 4C). Conversely, mice with an inactivation of membrane ER $\alpha$ (C451A) did not reveal any detectable alteration in the E4 action on the vagina structure or lubrication compared to wild-type mice (Figure 4D). These data indicate that selective activation of nuclear ER $\alpha$ is both necessary and sufficient to elicit morphological and functional benefits of E4 on the vagina.

\section{Discussion}

E4 is a natural estrogen with four hydroxyl groups produced exclusively during pregnancy by the human fetal liver. ${ }^{15}$ This steroid is detected in maternal plasma and urine during pregnancy; it also exhibits weak estrogenic agonist

Table 1 Analysis of Histomorphometry of the Vagina in $\mathrm{ER} \alpha^{+/+}$or $\mathrm{ER} \alpha^{-/-}$and $\mathrm{ER} \beta^{+/+}$or $\mathrm{ER} \beta^{-/-}$Mice Treated with Vehicle or E4

\begin{tabular}{|c|c|c|c|c|c|c|c|c|}
\hline \multirow[b]{3}{*}{ Variable } & \multicolumn{4}{|l|}{ Vehicle } & \multicolumn{4}{|c|}{ E4 (6 mg/kg per day) } \\
\hline & \multicolumn{2}{|l|}{$E R \alpha$} & \multicolumn{2}{|l|}{$E R \beta$} & \multicolumn{2}{|l|}{$E R \alpha$} & \multicolumn{2}{|l|}{$E R \beta$} \\
\hline & $E R \alpha^{+/+}$ & $E R \alpha^{-/-}$ & $E R \beta^{+/+}$ & $E R \beta^{-/-}$ & $E R \alpha^{+/+\star * *}$ & $E R \alpha^{-/-\star \star *}$ & $E R \beta^{+/+}$ & $E R \beta^{-/-}$ \\
\hline Epithelial height, $\mu \mathrm{m}$ & $9.2 \pm 0.7$ & $8.9 \pm 1.3$ & $11.7 \pm 5.4$ & $11.9 \pm 4.9$ & $89 \pm 20.6$ & $9.1 \pm 1.4$ & $75.1 \pm 18.6$ & $86.6 \pm 11.1$ \\
\hline Epithelial proliferation, \% & $5.3 \pm 1.1$ & $7 \pm 1.3$ & $7.2 \pm 4.2$ & $11.1 \pm 3.9$ & $37.3 \pm 5.0$ & $5.0 \pm 2.1$ & $34.3 \pm 3.7$ & $38.2 \pm 6.2$ \\
\hline Lubrication, mg & $0.4 \pm 0.1$ & $0.3 \pm 0.2$ & $0.1 \pm 0.1$ & $0.2 \pm 0.1$ & $1.3 \pm 0.3$ & $0.3 \pm 0.1$ & $1.0 \pm 0.3$ & $1.1 \pm 0.1$ \\
\hline
\end{tabular}

$n=8$ (two-factor analysis of variance). ${ }^{* * *} P<0.001$.

E4, estetrol; ER, estrogen receptor. 
A
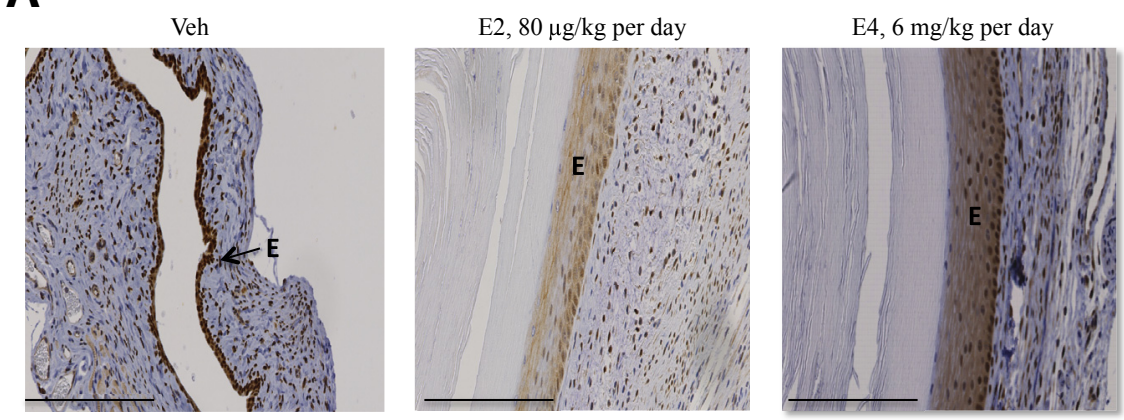

B
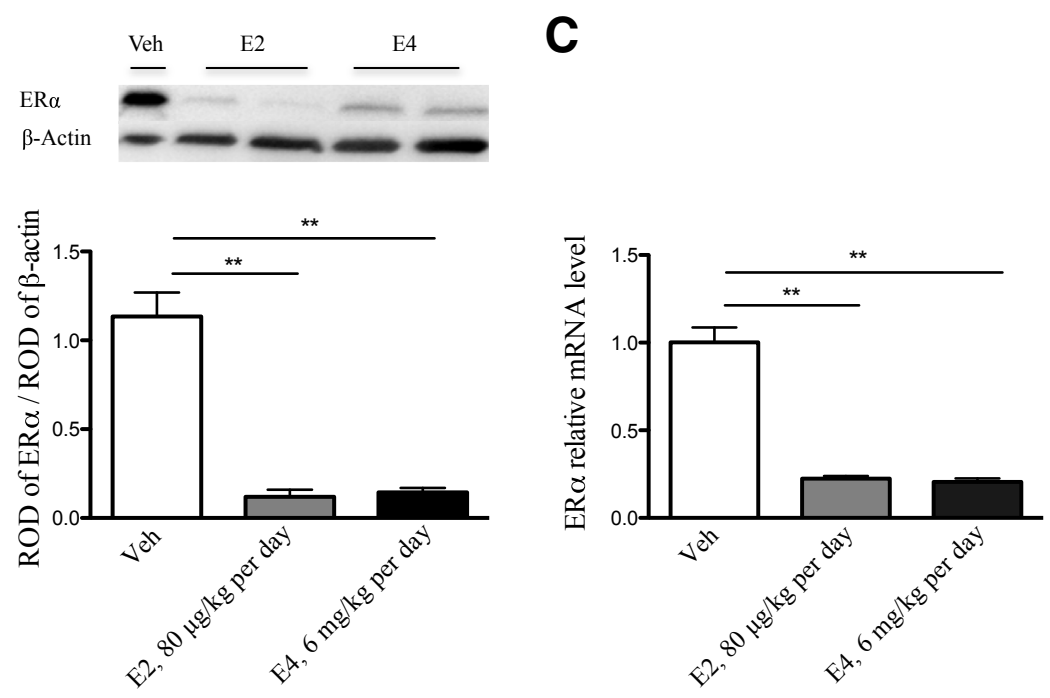

Figure 3 Abundance of estrogen receptor $\alpha$ $(E R \alpha)$ in the vagina of mice. A: $E R \alpha$ immunohistochemistry on transverse vaginal sections using MC-20 antibody. The arrowhead indicates the epithelium (E) in the first image. B: Representative Western blot analysis evaluating the expression of ER $\alpha$ with the $60 \mathrm{C}$ antibody on extracts from the mouse vagina. Results are normalized to $\beta$-actin expression. C: ER $\alpha$ mRNA analyzed by realtime quantitative PCR. Data are expressed as means \pm SD (B and C). $n=8$ (one-factor analysis of variance; $\mathbf{B}$ and $\mathbf{C})$. ${ }^{* *} P<0.01$. Scale bar $=$ $200 \mu \mathrm{m}($ A). Original magnification, $\times 20$ (A). E2, estradiol; E4, estetrol; ROD, relative optical density; Veh, vehicle. effects on the uterus. ${ }^{26,34}$ Clinical data obtained from a phase 2 clinical trial show that E4 has a lower impact on coagulation than 17-beta-estradiol or E2 and, thus, might have minimal impact on thromboembolic events. ${ }^{21}$ Moreover, recent studies reported that E4 has interesting properties on breast tissue, ${ }^{35,36}$ and we sought herein to evaluate extensively its effects on the vagina. We demonstrate that a chronic E4 treatment has a morphological and functional impact on the vagina of mice similar to that elicited by E2. Furthermore, we show that nuclear ER $\alpha$ activation is both necessary and sufficient to mediate these effects, whereas membrane $\mathrm{ER} \alpha$ is fully dispensable.

We have first demonstrated that ovariectomized mice treated with E4 (1 or $6 \mathrm{mg} / \mathrm{kg}$ per day) had an increased vaginal epithelial height. Consistently, Heegaard et $\mathrm{al}^{19}$ also reported a higher cornification in rats treated by $\mathrm{E} 4$. We report that the higher epithelial thickness elicited by E4 was secondary to a higher epithelial cell proliferation. This impact on epithelial length is of clinical interest because the decreased thickness and elasticity of the epithelial wall, followed by the exposition of the sensory nerve fibers of the stroma, are part of the mechanisms that explain dyspareunia. ${ }^{37,38}$ Thus, a normal epithelial wall may protect the vagina from trauma during coitus, and glycoprotein production is necessary for normal vaginal lubrication. ${ }^{39}$ Moreover, mice treated with E4 revealed an increased lubrication. Similarly, Kim et $\mathrm{al}^{40}$ found that ovariectomy led to a decrease of vaginal secretion compared to the control group, and E2 treatment restored the amount of vaginal secretion in ovariectomized rats.

This study showed, for the first time, that both E2 and E4 effects on the vagina are mediated through ER $\alpha$ and not ER $\beta .^{41}$ Both localizations within the vagina are important because E2-induced epithelial proliferation is mediated indirectly through stromal ER $\alpha$, in the vagina ${ }^{42}$ and in the uteri. ${ }^{41}$ These results suggest the importance of stromalepithelial interactions in the reproductive tissues, but the nature of these paracrine events and how they are modified by estrogens are unknown. Further studies could evaluate the different roles of stromal and epithelial ER $\alpha$ in E4induced vaginal proliferation, cornification, and stratification. In addition, we found that the decrease of the protein level of ER $\alpha$ was secondary to a down-regulation of ER $\alpha$ gene expression. Thus, the effect of E4 on ER $\alpha$ protein level was not secondary to a destruction, but to a decrease of ER $\alpha$ transcription.

Estrogens exert biological effects through activation of nuclear $\mathrm{ER} \alpha$, but a subset of membrane $\mathrm{ER} \alpha$, leading to 
A

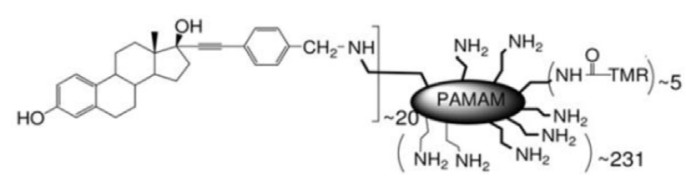

B

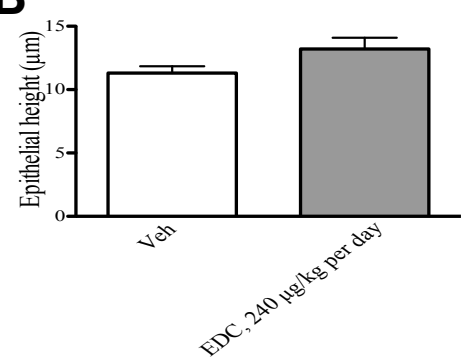

Vehicle

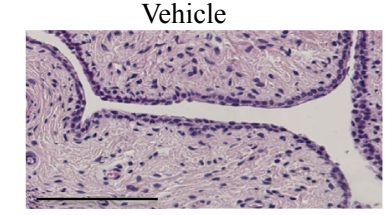

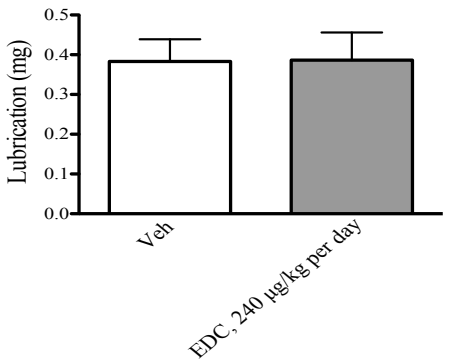

EDC, $240 \mu \mathrm{g} / \mathrm{kg}$ per day

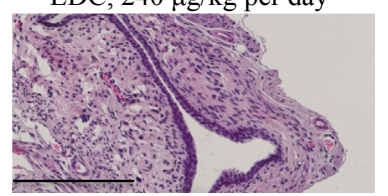

ER AF2

ER AF2

C

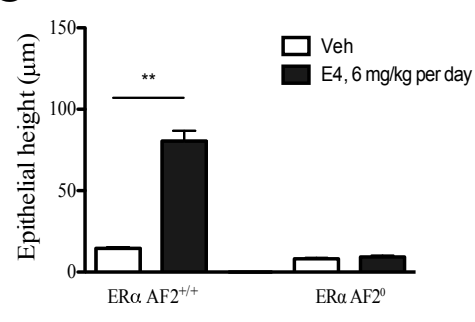

D D g

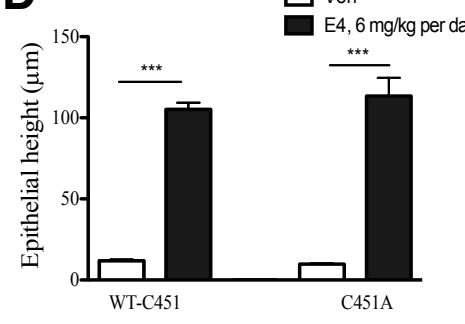

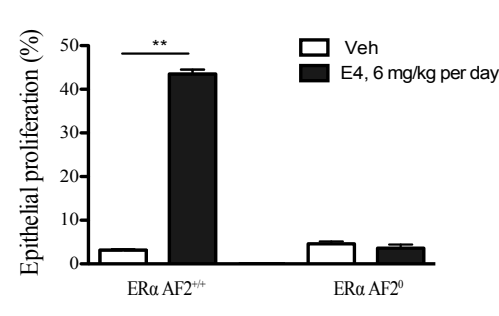
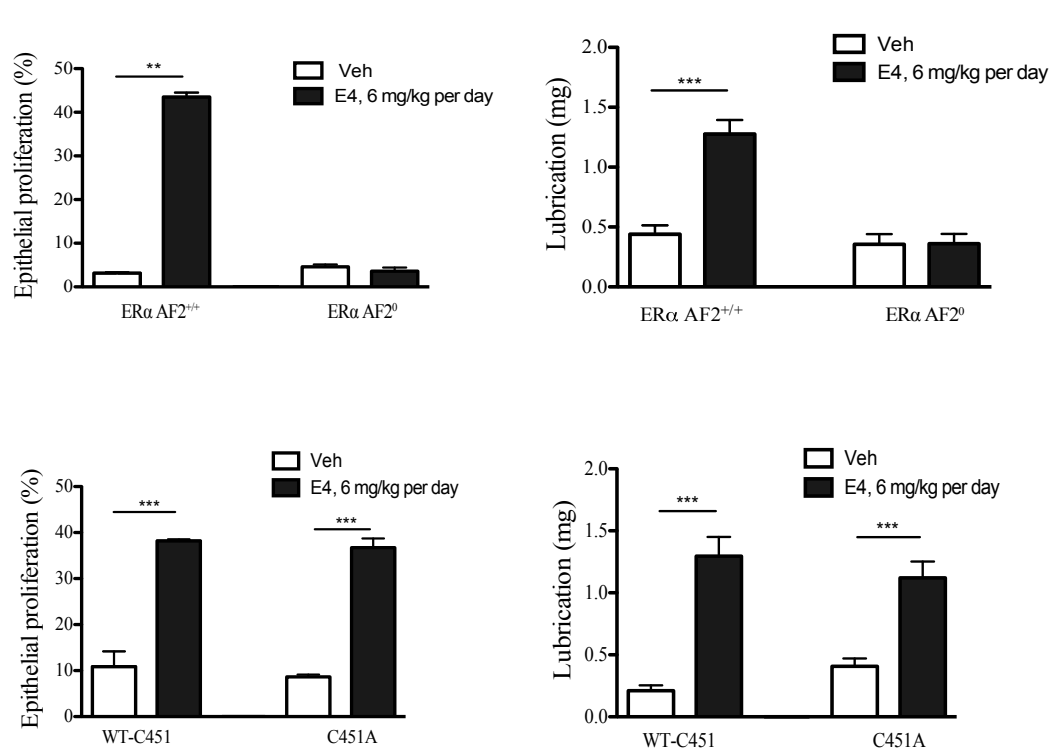

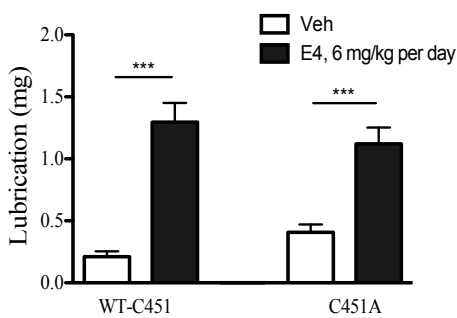

Figure 4 Analysis of membrane versus nuclear estrogen receptor $\alpha(E R \alpha)$ activation under estrogen chronic administration using pharmacological and genetic approaches. A: Chemical structures of estrogen-dendrimer conjugate (EDC). B: Luminal epithelial heights $(\mu \mathrm{m})$ and vaginal lubrication (mg) were evaluated in mice treated with a chronic administration of EDC. C and D: Luminal epithelial heights $(\mu \mathrm{m})$, epithelial proliferation (\%) and vaginal lubrication $(\mathrm{mg})$ were evaluated after chronic administartion of estetrol (E4; $6 \mathrm{mg} / \mathrm{kg}$ per day) in mice with ER $\alpha$-activation function inhibated ER $\alpha$ AF20 and in C451A-ER $\alpha$ mice. Data are expressed as means \pm SD (B-D). $n=6$ to 8 (two-factor analysis of variance; $\mathbf{B}-\mathbf{D}$ ). ${ }^{* *} P<0.01,{ }^{* * *} P<0.001$. Scale bar $=100 \mu \mathrm{m}(\mathbf{B})$. Veh, vehicle; WT, wild type.

membrane-initiated steroid signaling, was recently shown to play an important physiological role in fertility, bone, and endothelium. ${ }^{24,43}$ In the present study, we used the combination of pharmacological and genetic approaches to determine the respective roles of membrane and nuclear $\mathrm{ER} \alpha$ in the effect of $\mathrm{E} 4$ on the vagina. We first showed that mice treated by EDC, a selective agonist of the membrane $\mathrm{ER} \alpha$ or the vehicle, did not reveal any morphological or functional vaginal response, demonstrating that the activation of membrane ER $\alpha$ is not sufficient to mediate the effects of E4 on the vagina. We then explored the respective role of membrane and nuclear ER $\alpha$ using mutated mice.
C451-ER $\alpha$ mice presented the same favorable effect of E4 versus littermate mice. Altogether, membrane ER $\alpha$ activation is neither sufficient nor necessary to mediate the effect of estrogens in the vagina. Using $\mathrm{ER} \alpha \mathrm{AF} 2^{0}$, we showed that nuclear $\mathrm{ER} \alpha$ activation is absolutely necessary for $\mathrm{E} 4$ actions on the vagina.

These results have to be confirmed by phase 2 clinical studies with E4 orally given or locally applied. In addition, phase 2 and 3 trials need to document clinical effects on breast, bone, uterus, brain, and venous thromboembolism risk as well as sleep disturbances and vasomotor symptoms caused by the lack of estrogen during menopause. 


\section{Conclusion}

Symptoms of VVA represent a major health problem, concerning approximately $50 \%$ of women during and after menopause, and lead to a decrease of sexual activity and quality of life. Actually, E2 treatments decrease these symptoms, but their use is restricted by several adverse effects. We show herein that E4, a natural estrogen, is able to stimulate proliferation of the epithelium and to improve the function (lubrication) of the murine vagina. Furthermore, we demonstrated that the $\mathrm{E} 4$ action on this tissue can be entirely explained by its selective nuclear activation of ER $\alpha$, accounting for its efficiency similar to E2 in this sex target. Clinical studies are needed to confirm this important potential of E4 for the treatment of menopausal symptoms.

\section{Acknowledgments}

We thank the staff of the animal facilities and of the Functional Experimentation Platform for skillful technical assistance; and Marie-José Fouque, Guy Carcasses, Jean-José Maoret, and Frederic Martins for their excellent technical assistance and contribution to real-time quantitative PCR experiments performed at the GeT-TQ Genopole Toulouse Facility. EDC was kindly provided by Sung Hoon Kim, John A. Katzenellenbogen, and Benita S. Katzenellenbogen (University of Illinois at Urbana-Champaign).

T.B. is the guarantor of this work and, as such, had full access to all of the data in the study and takes responsibility for the integrity of the data and the accuracy of the data analysis.

\section{References}

1. Portman DJ, Gass ML; Vulvovaginal Atrophy Terminology Consensus Conference Panel: Genitourinary syndrome of menopause: new terminology for vulvovaginal atrophy from the International Society for the Study of Women's Sexual Health and the North American Menopause Society. Menopause 2014, 21:1063-1068

2. Pastore LM, Carter RA, Hulka BS, Wells E: Self-reported urogenital symptoms in postmenopausal women: women's health initiative Maturitas 2004, 49:292-303

3. Santoro N, Komi J: Prevalence and impact of vaginal symptoms among postmenopausal women. J Sex Med 2009, 6:2133-2142

4. Kingsberg SA, Wysocki S, Magnus L, Krychman ML: Vulvar and vaginal atrophy in postmenopausal women: findings from the REVIVE (REal Women's VIews of Treatment Options for Menopausal Vaginal ChangEs) survey. J Sex Med 2013, 10:1790-1799

5. Nappi RE, Palacios S: Impact of vulvovaginal atrophy on sexual health and quality of life at postmenopause. Climacteric 2014, 17:3-9

6. Bachmann GA, Nevadunsky NS: Diagnosis and treatment of atrophic vaginitis. Am Fam Physician 2000, 61:3090-3096

7. Archer DF: Efficacy and tolerability of local estrogen therapy for urogenital atrophy. Menopause 2010, 17:194-203

8. Sturdee DW, Panay N; International Menopause Society Writing Group: Recommendations for the management of postmenopausal vaginal atrophy. Climacteric 2010, 13:509-522

9. Rossouw JE, Anderson GL, Prentice RL, LaCroix AZ, Kooperberg C, Stefanick ML, Jackson RD, Beresford SA, Howard BV, Johnson KC,
Kotchen JM, Ockene J; Writing Group for the Women's Health Initiative Investigators: Risks and benefits of estrogen plus progestin in healthy postmenopausal women: principal results from the Women's Health Initiative randomized controlled trial. JAMA 2002, 288:321-333

10. MacLennan AH, Gill TK, Broadbent JL, Taylor AW: Continuing decline in hormone therapy use: population trends over 17 years. Climacteric 2009, 12:122-130

11. Rahn DD, Carberry C, Sanses TV, Mamik MM, Ward RM, Meriwether KV, Olivera CK, Abed H, Balk EM, Murphy M; Society of Gynecologic Surgeons Systematic Review Group: Vaginal estrogen for genitourinary syndrome of menopause: a systematic review. Obstet Gynecol 2014, 124:1147-1156

12. Suckling J, Lethaby A, Kennedy R: Local oestrogen for vaginal atrophy in postmenopausal women. Cochrane Database Syst Rev 2006: CD001500

13. Simunic V, Banovic I, Ciglar S, Jeren L, Pavicic Baldani D, Sprem M: Local estrogen treatment in patients with urogenital symptoms. Int J Gynaecol Obstet 2003, 82:187-197

14. Komm BS, Mirkin S: An overview of current and emerging SERMs. J Steroid Biochem Mol Biol 2014, 143:207-222

15. Hagen AA, Barr M, Diczfalusy E: Metabolism of 17-beta-oestradiol-414-C in early infancy. Acta Endocrinol 1965, 49:207-220

16. Apter D, Zimmerman Y, Beekman L, Mawet M, Maillard C, Foidart JM, Coelingh Bennink HJ: Bleeding pattern and cycle control with estetrol-containing combined oral contraceptives: results from a phase II, randomised, dose-finding study (FIESTA). Contraception 2016, 94:366-373

17. Duijkers IJ, Klipping C, Zimmerman Y, Appels N, Jost M, Maillard C, Mawet M, Foidart JM, Coelingh Bennink HJ: Inhibition of ovulation by administration of estetrol in combination with drospirenone or levonorgestrel: results of a phase II dose-finding pilot study. Eur J Contracept Reprod Health Care 2015, 20:476-489

18. Holinka CF, Brincat M, Coelingh Bennink HJ: Preventive effect of oral estetrol in a menopausal hot flush model. Climacteric 2008, 11(Suppl 1):15-21

19. Heegaard AM, Holinka CF, Kenemans P, Coelingh Bennink HJ: Estrogenic uterovaginal effects of oral estetrol in the modified AllenDoisy test. Climacteric 2008, 11(Suppl 1):22-28

20. Coelingh Bennink HJ, Verhoeven C, Zimmerman Y, Visser M, Foidart JM, Gemzell-Danielsson K: Clinical effects of the fetal estrogen estetrol in a multiple-rising-dose study in postmenopausal women. Maturitas 2016, 91:93-100

21. Kluft C, Zimmerman Y, Mawet M, Klipping C, Duijkers IJ, Neuteboom J, Foidart JM, Bennink HC: Reduced hemostatic effects with drospirenone-based oral contraceptives containing estetrol vs. ethinyl estradiol. Contraception 2016, 95:140-147

22. Ascenzi P, Bocedi A, Marino M: Structure-function relationship of estrogen receptor alpha and beta: impact on human health. Mol Aspects Med 2006, 27:299-402

23. Watson CS, Bulayeva NN, Wozniak AL, Finnerty CC: Signaling from the membrane via membrane estrogen receptor-alpha: estrogens, xenoestrogens, and phytoestrogens. Steroids 2005, 70:364-371

24. Adlanmerini M, Solinhac R, Abot A, Fabre A, Raymond-Letron I, Guihot AL, Boudou F, Sautier L, Vessieres E, Kim SH, Liere P, Fontaine C, Krust A, Chambon P, Katzenellenbogen JA, Gourdy P, Shaul PW, Henrion D, Arnal JF, Lenfant F: Mutation of the palmitoylation site of estrogen receptor alpha in vivo reveals tissue-specific roles for membrane versus nuclear actions. Proc Natl Acad Sci U S A 2014, 111:E283-E290

25. Billon-Gales A, Krust A, Fontaine C, Abot A, Flouriot G, Toutain C, Berges H, Gadeau AP, Lenfant F, Gourdy P, Chambon P, Arnal JF: Activation function 2 (AF2) of estrogen receptor-alpha is required for the atheroprotective action of estradiol but not to accelerate endothelial healing. Proc Natl Acad Sci U S A 2011, 108 : $13311-13316$

26. Abot A, Fontaine C, Buscato M, Solinhac R, Flouriot G, Fabre A, Drougard A, Rajan S, Laine M, Milon A, Muller I, Henrion D, 
Adlanmerini M, Valera MC, Gompel A, Gerard C, Pequeux C, Mestdagt M, Raymond-Letron I, Knauf C, Ferriere F, Valet P, Gourdy P, Katzenellenbogen BS, Katzenellenbogen JA, Lenfant F, Greene GL, Foidart JM, Arnal JF: The uterine and vascular actions of estetrol delineate a distinctive profile of estrogen receptor alpha modulation, uncoupling nuclear and membrane activation. EMBO Mol Med 2014, 6:1328-1346

27. Dupont S, Krust A, Gansmuller A, Dierich A, Chambon P, Mark M: Effect of single and compound knockouts of estrogen receptors alpha (ERalpha) and beta (ERbeta) on mouse reproductive phenotypes. Development 2000, 127:4277-4291

28. Harrington WR, Kim SH, Funk CC, Madak-Erdogan Z, Schiff R, Katzenellenbogen JA, Katzenellenbogen BS: Estrogen dendrimer conjugates that preferentially activate extranuclear, nongenomic versus genomic pathways of estrogen action. Mol Endocrinol 2006, 20:491-502

29. Stevis PE, Deecher DC, Suhadolnik L, Mallis LM, Frail DE: Differential effects of estradiol and estradiol-BSA conjugates. Endocrinology 1999, 140:5455-5458

30. Elhage R, Arnal JF, Pieraggi MT, Duverger N, Fievet C, Faye JC, Bayard F: 17 beta-Estradiol prevents fatty streak formation in apolipoprotein E-deficient mice. Arterioscler Thromb Vasc Biol 1997, 17: 2679-2684

31. Game X, Roumiguie M, Bouali O, Allard J, Gourdy P, Mazerolles C, Rischmann P, Arnal JF, Malavaud B: Vaginal lubrication after cervicovaginal stimulation is facilitated by phosphodiesterase type 5 inhibition in ovariectomized mice. J Sex Med 2013, 10:1452-1460

32. Abot A, Fontaine C, Raymond-Letron I, Flouriot G, Adlanmerini M, Buscato M, Otto C, Berges H, Laurell H, Gourdy P, Lenfant F, Arnal JF: The AF-1 activation function of estrogen receptor alpha is necessary and sufficient for uterine epithelial cell proliferation in vivo. Endocrinology 2013, 154:2222-2233

33. Couse JF, Lindzey J, Grandien K, Gustafsson JA, Korach KS: Tissue distribution and quantitative analysis of estrogen receptor-alpha (ERalpha) and estrogen receptor-beta (ERbeta) messenger ribonucleic acid in the wild-type and ERalpha-knockout mouse. Endocrinology 1997, 138:4613-4621

34. Holinka CF, Gurpide E: In vivo effects of estetrol on the immature rat uterus. Biol Reprod 1979, 20:242-246
35. Gerard C, Mestdagt M, Tskitishvili E, Communal L, Gompel A, Silva E, Arnal JF, Lenfant F, Noel A, Foidart JM, Pequeux C: Combined estrogenic and anti-estrogenic properties of estetrol on breast cancer may provide a safe therapeutic window for the treatment of menopausal symptoms. Oncotarget 2015, 6: $17621-17636$

36. Gerard C, Blacher S, Communal L, Courtin A, Tskitishvili E, Mestdagt M, Munaut C, Noel A, Gompel A, Pequeux C, Foidart JM: Estetrol is a weak estrogen antagonizing estradiol-dependent mammary gland proliferation. J Endocrinol 2015, 224:85-95

37. Kingsberg SA, Krychman ML: Resistance and barriers to local estrogen therapy in women with atrophic vaginitis. J Sex Med 2013, 10: $1567-1574$

38. Erol B, Tefekli A, Ozbey I, Salman F, Dincag N, Kadioglu A, Tellaloglu S: Sexual dysfunction in type II diabetic females: a comparative study. J Sex Marital Ther 2002, 28(Suppl 1):55-62

39. Gorodeski GI: Estrogen modulation of epithelial permeability in cervical-vaginal cells of premenopausal and postmenopausal women. Menopause 2007, 14:1012-1019

40. Kim SO, Lee HS, Ahn K, Park K: Effect of estrogen deprivation on the expression of aquaporins and nitric oxide synthases in rat vagina. J Sex Med 2009, 6:1579-1586

41. Cooke PS, Buchanan DL, Young P, Setiawan T, Brody J, Korach KS, Taylor J, Lubahn DB, Cunha GR: Stromal estrogen receptors mediate mitogenic effects of estradiol on uterine epithelium. Proc Natl Acad Sci U S A 1997, 94:6535-6540

42. Buchanan DL, Kurita T, Taylor JA, Lubahn DB, Cunha GR, Cooke PS: Role of stromal and epithelial estrogen receptors in vaginal epithelial proliferation, stratification, and cornification. Endocrinology 1998, 139:4345-4352

43. Smirnova NF, Fontaine C, Buscato M, Lupieri A, Vinel A, Valera MC, Guillaume M, Malet N, Foidart JM, RaymondLetron I, Lenfant F, Gourdy P, Katzenellenbogen BS, Katzenellenbogen JA, Laffargue M, Arnal JF: The activation function-1 of estrogen receptor alpha prevents arterial neointima development through a direct effect on smooth muscle cells. Circ Res 2015, 117:770-778 